\title{
HPLC QUANTIFICATION OF LACTOPEROXIDASE IN THERAPEUTIC DAIRY WASTE ENRICHED BY BUBBLESEPARATION
}

\author{
PRABIR K. DATTA ${ }^{\mathrm{a}^{*}, \text { GOUTAM MUKHOPADHAYAY }^{\mathrm{b}} \text {, AMITAVO GHOSH }}$
}

${ }^{*}$ Bengal College of Pharmaceutical Sciences and Research, Durgapur 713212 India, ${ }^{b}$. C. D. A. College of Pharmacy and Technology, Barasat, Kolkata 700127, India, 'Research Assistant, Flinders University, Australia 5001

Email: pkdatta57@gmail.com

Received: 23 Jan 2019, Revised and Accepted: 11 Apr 2019

\section{ABSTRACT}

Objective: The objective of this study was to enrich therapeutic proteins and remove pollutants from dairy wastewater for establishing foam fractionation as a lucrative unit operation.

Methods: Dairy wastewater collected from dairy industry was processed to fat-free dried protein waste mass diluted to 1-liter feed by distilled water in different concentrations and foam fractionated by sodium dodecyl sulphate (surfactant) to enriched proteins extract (foamate) in a foam fractionator. Foamate were analysed to quantify total proteins and lacto peroxidase respectively. The efficiency was evaluated by varying parameters like $\mathrm{pH}$, initial waste and ionic concentrations, the waste-surfactant mass ratio of feed and flow rate of gas $\left(\mathrm{N}_{2}\right)$ through feed solution by several experiments. Heat of desorption $(\lambda)$ and mass transfer coefficient $(K)$ were determined as indicators of adsorptive bubble separation to foam phase governed by Gibb's equation of adsorption isotherm.

Results: The process was optimized at $\mathrm{pH} 5.5$, initial feed concentration $500 \mu \mathrm{g} / \mathrm{ml}$, waste-surfactant mass ratio (1.5:1), gas flow rate (350 $\mathrm{ml} / \mathrm{min})$ and ionic concentration 0.1 gram-mole of NaCL per litre of feed with enrichment factor (49.09), percent recovery (98.18\%) observed in foamate. One natural preservative specifically lactoperoxidase was quantified by RP-HPLC analysis as $0.49 \%(\mathrm{w} / \mathrm{w})$ of total proteins at optimal condition. Heat of desorption $(\lambda)$, mass transfer coefficient $(\mathrm{K})$ were determined $3140 \mathrm{cal} / \mathrm{mol}$ and $12.68^{*} 10^{-9} \mathrm{~mol} / \mathrm{cal} / \mathrm{cm}^{2} / \mathrm{s}$ respectively at $\mathrm{pH} 8.5$, initial feed concentration $500 \mu \mathrm{g} / \mathrm{ml}$ and gas flow rate $350 \mathrm{ml} / \mathrm{min}$.

Conclusion: The method may be a useful unit operation for recovery of biomolecules and removal of toxic pollutants from industrial wastewater for coming days.

Keywords: Foam fractionation, Sodium dodecyl sulphate, Enrichment, Lactoperoxidase, Medicinal proteins, RP-HPLC

(C) 2019 The Authors. Published by Innovare Academic Sciences Pvt Ltd. This is an open-access article under the CC BY license (http://creativecommons.org/licenses/by/4.0/) DOI: http://dx.doi.org/10.22159/ijap.2019v11i4.32058

\section{INTRODUCTION}

Worldwide milk production rising every year by more than $1 \%$ that reached around 800 tons in the year of 2017. India will become the leading milk production country for the coming year, 2026. Under these circumstances, huge amount of dairy wastes will be generating from various dairy products such as milk, yoghurt, desserts and custards, cheese, butter, milk powders etc. Dairy wastewater contains a variety of therapeutic wastes along with other compounds [1-3].

In this context, application of the lucrative technique for co-product recovery from dairy wastewater is very significant to serve the dual purpose for controlling environmental pollution as well as recovery of pharmaceutical and nutritional dairy waste such as the variety of proteins and other molecules for the health of man and animal kingdom. The currently applied techniques like ultrafiltration, Nano filtration, electrodialysis, ion-exchange, gel-filtration, precipitation and coagulation are expensive. Hence, it is necessary to search substitute gainful techniques of therapeutic assistance for the coming days. Foam fractionation provides various benefit like easy scale-up, nonstop operation, suitable for refinement of heat sensitive molecules in the biotechnological process pathway without application of heat, limited space, low power consumption, no additional cost of solvent and high yield for dilute feed. The technique is under the foam division of "Adsorptive Bubble Separation Method" proposed by Robert Lemlich in his edited book [4]. The principle of separation of the technique is based on physical or chemical adsorption of surface active molecules on the gas-liquid interface (bubble's surface). The amount of surface active molecules adsorbed can be quantitatively expressed by Gibb's Equation of Adsorption Isotherm [4, 5].

Numerous researchers applied this technique in the field of pharmaceutical biotechnology for enrichment, purification and extraction of thermolabile medicinal proteins and a variety of natural pharmaceuticals from plant extracts and bio-sources [6-8].
This technique has also been applied for removal of toxic metals and chemicals from industrial waste streams [9-11].

The dairy wastewater chiefly contains a mixture of medicinal proteins namely bovine serum albumin (BSA), alpha-lactalbumin $(\alpha-$ LA), beta-lactoglobulin ( $\beta-\mathrm{LG})$, immunoglobulin (IG) [major proteins] as well as bovine lactoferrin (BLF) and bovine lactoperoxidase (BLP)[minor proteins]. Lactoperoxidase is a natural preservative free from an untoward effect on the human body and useful anticaries component in toothpaste formula [1,12-15]. It may be used as a harmless preservative in pharmaceutical and food products. The proteins under study have isoelectric $\mathrm{pH}(\mathrm{pI})$ at approximately 5.5(major) and 9.0(minor) respectively [16, 17]. In this study, we assessed the batch process of foam fractionation for the enrichment of multicomponent proteins mixture from dilute dairy waste. In addition, RP-HPLC analysis was performed to measure the quantity of single protein (lactoperoxidase) present in enriched protein mixture of formate by foam fractionation.

\section{MATERIALS AND METHODS}

\section{Materials}

Dairy wastewater was collected from local dairy industry (Kolkata). BLP was obtained as a gift sample from S. A. Pharma Chem. Pvt. Ltd., India. AR grade Sodium dodecyl sulphate (SDS), sodium chloride (NaCL), acetonitrile $(\mathrm{ACN})$, methanol $(\mathrm{CH} 3 \mathrm{OH})$, trifluoroacetic acid (TFA)(all HPLC grade), concentrated hydrochloric acid (HCL) and sodium hydroxide $(\mathrm{NaOH})$ were procured from E. Merk Ltd (Mumbai, India). All other solvents used were of analytical grade, procured from E. Merk.

\section{Methods}

Initial processing of dairy wastewater

Dairy wastewater was filtered through muslin cloth and centrifuged (Remi, India) several times) for removal of fat from wastewater till 
constant absorbance(UV-1800,Shimadzu,Japan) was recorded and $250 \mathrm{ml}$ of such processed dairy protein solution was evaporated at $45{ }^{\circ} \mathrm{C}$ for $4 \mathrm{~h}$ by using Eyela rotary evaporator (Indosathi scientific lab, India) to dried protein mass. The obtained mass (195g) was preserved in a refrigerator at $\left(-18^{\circ} \mathrm{C}\right)$ until use.

\section{Preparation of standard curve for total protein quantification}

The protein mass was diluted in the concentration range of 50-900 $\mu \mathrm{g} / \mathrm{ml}$ in double distilled water and absorbance of each concentration was determined in a spectrophotometer(UV1800 ,Shimadzu,Japan) at wavelength $280 \mathrm{~nm}$ to draw the standard curve of protein waste powder solution essential for the analysis of total protein extracted in foamate.
Determination of critical micelle concentration and isoelectric $\mathrm{pH}$ of total and target protein (BLP) by surface tension $(\gamma)$ method at operating temperature $20-25^{\circ} \mathrm{C}$

Surface tensions of different concentrations $(50-900 \mu \mathrm{g} / \mathrm{ml})$ of processed dairy protein waste in double distilled water were determined in a tensiometer by interfacial surface tension method to find out critical micelle concentration (CMC) [fig. 1]. The slope of surface tension $(\gamma)$ vs concentration (c) plot will give the value of the molar quantity of therapeutic proteins adsorbed on the surface of the bubble ( $\tau$ value) which is calculated from Gibb's equation. The isoelectric $\mathrm{pH}$ of BLP (target protein), as well as dairy waste protein solution, were determined at different $\mathrm{pH}$ by using $0.1(\mathrm{~N}) \mathrm{HCL}$ and $0.1(\mathrm{~N}) \mathrm{NaOH}$ below CMC by tensiometer (Deeksha instrument corporation, India) [18].



Fig. 1: Plot of surface tension vs concentration of dairy protein waste solution

Table 1: Characteristics of medicinal proteins in dairy waste

\begin{tabular}{|c|c|c|c|c|c|}
\hline Medicinal protein in dairy waste & $\begin{array}{l}\text { Mol. wt. } \\
\left(\mathrm{Da}^{*} 10^{3}\right)\end{array}$ & Isoelectric pH(pI) & 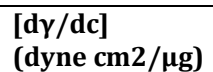 & $\begin{array}{l}\text { Range of conc. }(\mu \mathrm{g} / \mathrm{ml}) \\
\text { of constant slope }\end{array}$ & $\begin{array}{l}\text { CMC } \\
(\mu \mathrm{g} / \mathrm{ml})\end{array}$ \\
\hline BSA(major) & 69 & 5.1 & $-\ldots$ & --.--- & ---- \\
\hline BLF(minor) & 84 & 9.0 & ----- & ------ & --.-- \\
\hline BLP(minor) & 89 & 9.6 & 0.059 & $5-175$ & 175 \\
\hline$\alpha$-LA(major) & 14 & 5.3 & ----- & ------ & $-\cdots---$ \\
\hline$\beta$-LG(major) & 18.30 & 4.8 & ----- & ------ & ----- \\
\hline IG(major) & 100 & 5.5 & ----- & ------ & ----- \\
\hline Dil. protein waste & 25.60 & 5.2 & 0.329 & $50-750$ & 750 \\
\hline Dil.(Protein waste+SDS) $[1.5: 1(\mathrm{w} / \mathrm{w})]$ & ------ & ------ & 0.301 & $85-800$ & 800 \\
\hline
\end{tabular}

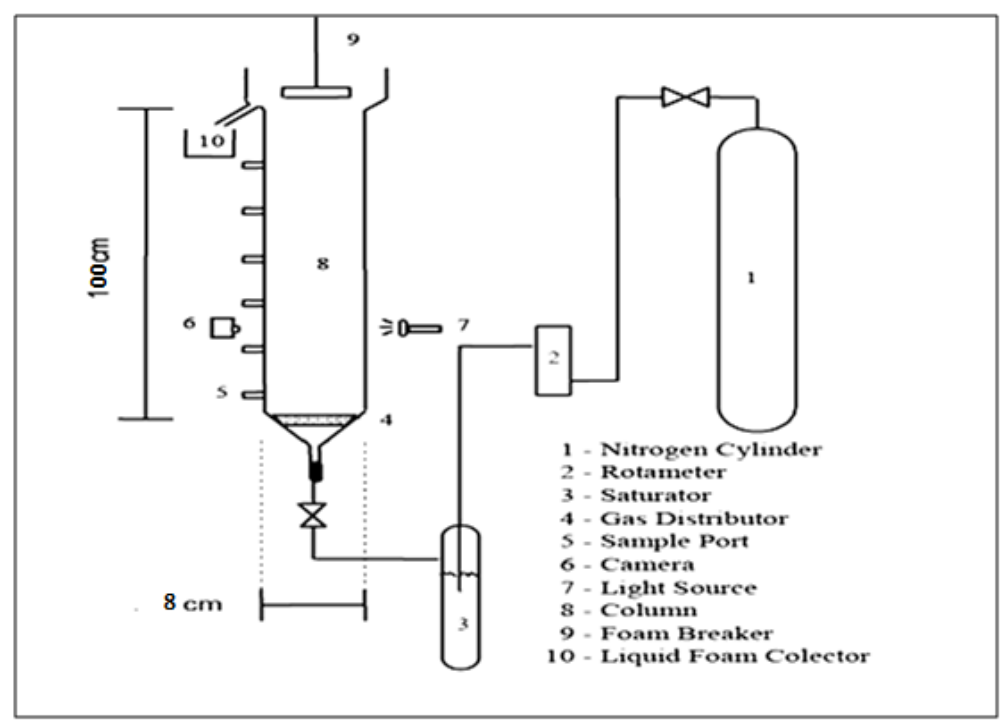

Fig. 2: Experimental set up for foam fractionation 


\section{Foam fractionation}

The experimental foam fractionator (fabricated by the local fabricator in Kolkata, India) consists of a glass column $(100 \mathrm{~cm}$ length) and internal diameter $(8 \mathrm{~cm})$ with the thickness of $0.5 \mathrm{~cm}$ which was attached with nitrogen gas cylinder as the source of gas supply for the formation of bubbles by a glass porous frit no. G3 (1540 micron porosity) fused at the base of the column (fig. 2). The dilute feed (1L) was prepared from processed dairy waste by adding SDS with varying mass ratios and concentration of total proteins in the foamate was determined by spectrophotometric analysis (UV1800, Shimadzu, Japan) at wavelength $280 \mathrm{~nm}$. The separation efficiency of the experiment was optimized at pH5.5 of feed solution, gas flow rate $350 \mathrm{ml} / \mathrm{min}$, waste-surfactant mass ratio (WSR=1.5:1 $\mathrm{w} / \mathrm{w})$, initial dairy waste concentration $\left(\mathrm{C}_{\mathrm{l}}=500 \mu \mathrm{g} / \mathrm{ml}\right)$ and ionic concentration of feed(IC) by adding $0.1 \mathrm{~g}$ mole of $\mathrm{NaCl}$ per litre of feed solution. The $\mathrm{pH}$ of dilute feed was adjusted with 0.1(M) of HCL or $\mathrm{NaOH}$ solution. The gas flow rate (GFR) in $\mathrm{ml} / \mathrm{min}$ was kept under observation by the rotameter. The GFR, $\mathrm{pH}$ of the feed solution, $\mathrm{I}_{\mathrm{C}}$, initial feed concentration $\left(\mathrm{C}_{\mathrm{I}}\right)$ and WSR were varied to find an impact on the adsorptive separation efficiency of total protein in foamate. Gas bubbles generated by the sparger (bubbles distributor through feed solution) ascend through the column and deposit as foam over the dilute feed. The aggregated bubbles in the form of foam with adsorbed surface-active molecules (total dairy proteins from dilute waste solution as feed) by formation of complex with SDS (surfactant) as well as due to individual surface active properties move upward by the pressure of gas passing through the feed solution in the column and finally collected as foamate from the top outlet of the column which is converted into concentrated extract by foam breaker (Remi, India). The weight, volume of foamate and foam breaking time were accurately calculated for analysis and determination of foam strength respectively. Foamate samples were withdrawn at different time intervals $(5,15,25,35,45,55 \mathrm{~min})$ and foamate extract analysed to quantify total proteins by spectrophotometer (UV-1800, Shimadzu, Japan) and by RP-HPLC (Waters, MA, USA) for analysis of BLP.

\section{Evolution of performance}

Performance of foam fractionation are indicated by three parameters namely (i) enrichment ratio $\left(E_{R}\right)$ equal to the ratio of $\mathrm{C}_{S} / \mathrm{C}_{\mathrm{I}}$, where $\mathrm{C}_{S}$ is the concentration of protein in foamate and $\mathrm{C}_{\mathrm{I}}$ is the initial concentration in feed, (ii) percent recovery (\%Rp) calculated by the ratio of amount of protein in foamate $\left(\mathrm{A}_{\mathrm{FM}}\right)$ to the amount of protein in feed $\left(\mathrm{A}_{\mathrm{FD}}\right)$ multiplied by $100\left[\% \mathrm{Rp}=\left(\mathrm{A}_{\mathrm{FM}} / \mathrm{A}_{\mathrm{FD}}\right)\right.$ * $100]$ and (iii) separation ratio $\left(S_{R}\right)$ is equal to the ratio of $C_{S} / C_{R}$, where $C_{R}$ is expressed as concentration in residual solution. The highest values indicate the optimum efficiency of separation of proteins to the foam phase.

\section{Quantification of total protein mixture in foamate by UV absorbance}

The total protein in foamate, feed and residue in foam fractionation experiments were quantified at wave length $280 \mathrm{~nm}$ by using spectrophotometer (UV-1800, Shimadzu, Japan) [19].

\section{HPLC analysis of BLP in foamate extract}

The HPLC system (Waters, MA, USA) was consisted of Symmetry 300 $\mathrm{C}_{4}$ protein analysis column $(50 \mathrm{~mm} \times 4.6 \mathrm{~mm}$; particle size $5 \mu \mathrm{m}$; pore size $300 \AA$ ) and equipped with a guard column. The temperature of the column was kept at $25{ }^{\circ} \mathrm{C}$. The analysis was consisted of a 600 controller pump, a multiple-wavelength ultraviolet-visible (UV-Vis) detector equipped with $50 \mu \mathrm{l}$ loop injector (Rheodyne \pm , Cotati, CA, USA). The outputs were processed and recorded in a compatible integrator (model 486, Waters, MA, USA).

HPLC assays were performed using an isocratic system of $0.1 \%$ trifluoroacetic acid (TFA) in water (A) and acetonitrile (ACN) (B) with the ratio of $95: 5(\mathrm{v} / \mathrm{v})$. The run time was set at $30 \mathrm{~min}$. The Flow rate was set at $1.0 \mathrm{ml} / \mathrm{min}$ and the absorbance was detected at $220 \mathrm{~nm}$.

\section{Studies on an interfacial area of adsorption}

Determination of surface area of adsorption is important to determine the mass transfer coefficient $(\mathrm{K})$ of protein molecules to foam phase [19]. The interfacial area is calculated by the following in equation 1.

$$
A s=\frac{6 A_{C} H \varepsilon}{d_{32}}---------------(1)
$$

Where $\mathrm{H}$ is the height of liquid feed in the column, $\mathrm{A}_{c}$ is the column cross-sectional area (in this case $50.25 \mathrm{~cm}^{2}$ ), $A_{s}$ is the interfacial area of foam phase for adsorption, $\varepsilon$ is the void fraction determined from $\%$ gas hold up and $\mathrm{d}_{32}$ is bubble sauter mean diameter for individual location determined by equation 2 .

$$
\overline{d_{32}}=\frac{\sum d^{3}}{\sum d^{2}}----------(2)
$$

$d_{32}$ is the bubble mean sauter diameter given by equation 3 , where $(\mathrm{k})$ is the number of locations (in this case 4) of the column where bubbles photograph taken.

$$
d_{32}=\frac{k}{\sum \frac{1}{d_{32}}}-\cdots------(3)
$$

Gas was passed at varying GFR (250,300 and $350 \mathrm{ml} / \mathrm{min}$ respectively) through 1liter feed solution and bubbles were photographed at 4 different locations namely 5, 15, 25 and $35 \mathrm{~cm}$ vertical distances from the sparger (fig. 3). The photograph was developed in the computer and bubbles diameter was determined manually by super pixel scale after enlargement. 160-165 such bubbles were measured for each plate and mean sauter bubble diameter $\left(\mathrm{d}_{32}\right)$ was calculated for respective flow rate. Data were recorded in table 2 [19].

The percentage gas hold up $\left(\varepsilon^{*}\right)$ was also calculated for different superficial gas velocities through the liquid feed from the maximum drop in liquid level $(\Delta \mathrm{L})$ from initial level (L) by sudden stoppage of the gas supply by equation (4). Data were tabulated in table 2 and relation with interfacial area represented by fig. 4 .

\begin{tabular}{|c|c|c|c|c|c|c|c|}
\hline SGV (cm/s) & $\begin{array}{l}\text { GFR } \\
(\mathrm{ml} / \mathrm{min})\end{array}$ & $\begin{array}{l}\text { Sauter mean } \\
\text { diameter } \\
\mathbf{d}_{32}(\mathrm{~cm})\end{array}$ & $\begin{array}{l}\text { \%gas hold up } \\
\left(\varepsilon^{*} 100\right)\end{array}$ & Interfacial area $\left(\mathrm{cm}^{2}\right)$ & $\begin{array}{l}\text { Percent recovery } \\
(\% \mathrm{Rp})\end{array}$ & $\begin{array}{l}\text { Feed density } \\
\text { (g/cc) }\end{array}$ & $\begin{array}{l}\text { Feed } \\
\text { viscosity } \\
\text { (Poise) }\end{array}$ \\
\hline 0.083 & 250 & 0.0621 & 0.90 & 845.09 & 90.98 & 1.235 & 0.0095 \\
\hline 0.099 & 300 & 0.0705 & 1.19 & 1012.85 & 93.99 & & \\
\hline 0.116 & 350 & 0.0821 & 1.38 & 1117.29 & 98.18 & & \\
\hline
\end{tabular}

$$
\left(\varepsilon^{*}\right)=\frac{\Delta \mathrm{L}}{\mathrm{L}} * 100
$$

Table 2: Effect of superficial gas velocity (SGV) on interfacial area

Table 3: Effect of molar ionic concentration(IC) on ( $\left.E_{R}\right)$ and (\% Rp)

\begin{tabular}{llll}
\hline Molar ionic concentration $\left(I_{C}\right)$ & Percent gas hold up $\left(\varepsilon^{*}\right)$ & Enrichment ratio $\left(E_{\mathrm{R}}\right)$ & Percent recovery $(\% R p)$ \\
\hline 0.0125 & 0.70 & 32.80 & 70.40 \\
0.05 & 0.785 & 33.39 & 78.80 \\
0.1 & 0.905 & 40.45 & 90.99 \\
0.15 & 0.810 & 36.52 & 80.35 \\
\hline
\end{tabular}




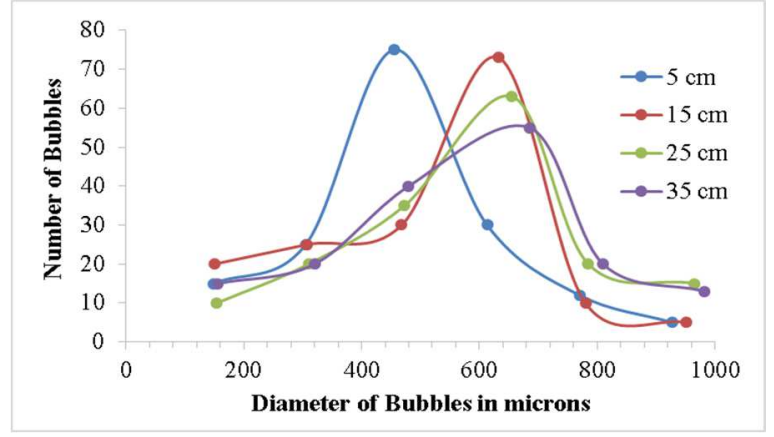

Fig. 3: Bubble distribution at SGV $0.083 \mathrm{~cm} / \mathrm{s}$

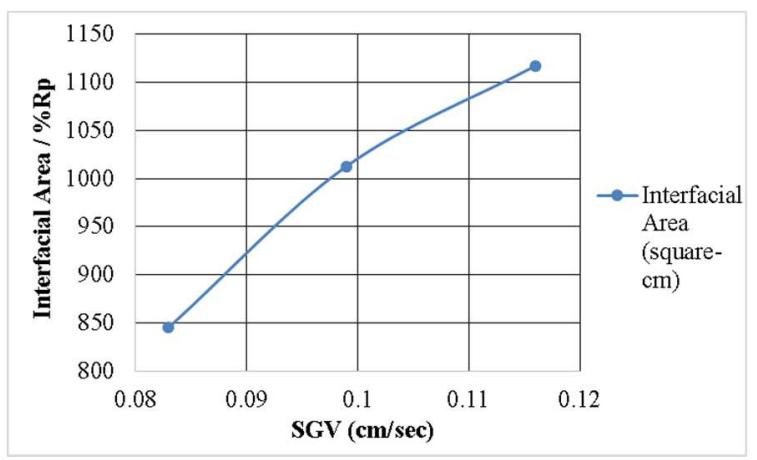

Fig. 4: Effect of superficial gas velocity on the interfacial area

Where $\Delta \mathrm{L}$ is the maximum drop in liquid level and $\mathrm{L}$ is the initial level of the liquid pool. Void fraction $(\varepsilon)$ multiplied by 100 will give the percentage gas hold up.

\section{Studies of the effect of ionic concentration on gas hold up}

The effect of ionic concentration in feed on gas hold-up percent $\left(\varepsilon^{*}\right)$,enrichment ratio $\left(E_{R}\right)$ and percent recovery $(\% R p)$ was studied at a fixed GFR(250 $\mathrm{ml} / \mathrm{min}), \mathrm{C}_{\mathrm{I}}(500 \mu \mathrm{g} / \mathrm{min}), \mathrm{pH} 5.5$ and WSR 1.5:1(w/w). Four different concentrations namely 0.0125, 0.050 .10 and $0.15 \mathrm{~g} \mathrm{~mol}$ of $\mathrm{NaCL} / \mathrm{l}$ of feed were chosen for the study and data recorded in (table 3 and shown by fig. 5) [20].

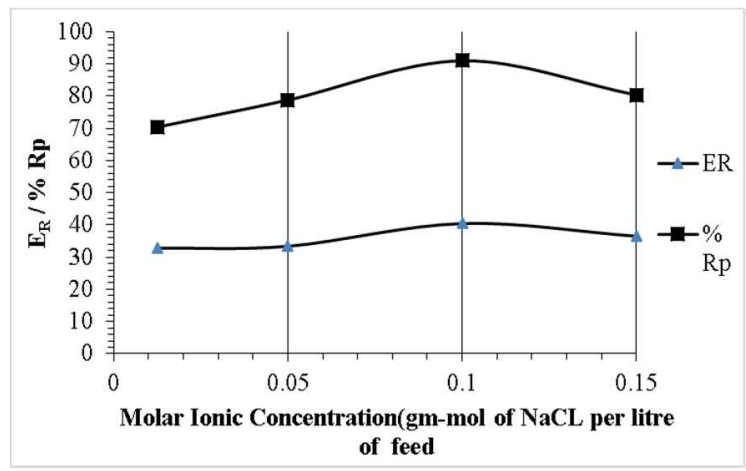

Fig. 5: Effect of ionic concentration on $E_{R}$ and \% Rp

\section{Theory of molar mass transfer to the foam phase}

By application of material balance for surface active proteins in the two-phase system (liquid and foam), we can determine experimentally the latent heat of desorption $(\lambda)$ by equation (5) and mass transfer coefficient (K) by equation (6) respectively from the known value of $\lambda$. These two parameters are the markers for the separation of protein molecules to the foam phase [4].

$$
\begin{gathered}
\ln \left[\frac{V_{O}}{V_{B}}\right]=\frac{1}{\left(e \lambda^{\prime R T}-1\right)} \ln \left[\frac{C_{O}}{C_{B}}\right]---------------(5) \\
\int_{C_{S_{S}}}^{C_{S}}\left[\frac{d(C s)}{\left.\lambda-R T \ln \frac{C_{S}}{C_{B}}\right]}=K\left(\frac{A_{S}}{V_{S}}\right) \int_{0}^{\theta} d \theta=K A s \theta / V s^{-----------(6)}\right.
\end{gathered}
$$

Where, $\mathrm{V}_{0}=$ initial bulk volume of liquid(ml) at zero time $(\theta=0), \mathrm{V}_{\mathrm{B}}=$ bulk volume of liquid $(\mathrm{ml})$ after any time $(\theta \mathrm{min}), \mathrm{V}_{\mathrm{S}}=$ volume of liquid of foam phase at any time $(\theta), C_{0}=$ concentration in bulk at time $(\theta=0), C_{B}=$ protein concentration in bulk $(\mu \mathrm{g} / \mathrm{ml})$ after any time $(\theta), C_{s}=$ protein concentration $(\mu \mathrm{g} / \mathrm{ml})$ in foam phase after any time $(\theta \min ), \mathrm{T}(\mathrm{K})=$ absolute operating temperature, $\mathrm{R}=$ gas molar constant $=8.3143^{*} 10^{7} \mathrm{ergs} /$ degree $/ \mathrm{mol}, \mathrm{As}_{\mathrm{s}}=$ interfacial area in $\mathrm{cm}^{2}$, $\theta=$ residence time of foam phase obtained from the volumetric flow rate of bubbles and the height of the column, $\lambda$, the latent heat of desorption in $\mathrm{cal} / \mathrm{mol}$ can be determined from the slope $\left[1 /\left(\mathrm{e}^{\lambda / \mathrm{RT}}\right.\right.$. 1)] of $\ln \left[V_{0} / V_{B}\right]$ vs. [ln $\left.C_{0} / C_{B}\right]$ plot [ equation 5, fig. 6][4].

For determination of $\mathrm{K}$, the left-hand side integral of equation (6)was determined by graphical integration of $\left[\lambda-R T \ln \left(\mathrm{C}_{\mathrm{S}} / \mathrm{C}_{\mathrm{B}}\right)\right]$ ${ }^{1} \mathrm{vs}$. [ $\mathrm{C}_{\mathrm{S}}$ ] plot initiating from $\mathrm{C}_{\mathrm{S} 0}$ to $\mathrm{C}_{\mathrm{S}}$ by determining different values of area under curve those are integrals of $\left[\lambda-R T \ln \left(\mathrm{C}_{S} / \mathrm{C}_{B}\right)\right]^{-1}$ at different intervals of foamate collection i.e.(0-5), (5-15),(15-25),(25-35) mins etc. The different values of integrals i.e. $\mathrm{CS}^{*}\left[\lambda-\mathrm{RT} \ln \left(\mathrm{C}_{S} / \mathrm{C}_{\mathrm{B}}\right)\right]^{-1 *} 10^{7}$ were plotted against different collection times $(\theta=t)$ and the slope $(\mathrm{m})$ of the line was equal to the value of, $\mathrm{m}=\left[\mathrm{K}\left(\mathrm{A}_{\mathrm{s}} / \mathrm{V}_{\mathrm{S}}\right)\right]($ fig. 7 and equation 6$)$. The foam thickness $[t]=\left[\right.$ Volume of foam $\left(V_{s}\right) /$ area of foam $\left.\left(A_{s}\right)\right]$ was determined by Gibb's equation: $\left(e^{\lambda / R T}-1\right)=(1 / t$ RT $)$ $*(-\mathrm{d} \gamma / \mathrm{dC})$ and " $\mathrm{t}$ " value can be calculated from $\mathrm{R}\left(=8.317^{*} 10^{7} \mathrm{ergs} /\right.$ $\left.{ }^{\circ} \mathrm{C} / \mathrm{mole}\right), \mathrm{T}(=298 \mathrm{~K}),(-\mathrm{d} \gamma / \mathrm{dC})=0.329$ (from table1), $\lambda$ and average mol. wt. $(25,600)$ of dairy proteins waste. The mass transfer coefficient $(K)$ was determined from the measured value of $t$ and value of slope $(\mathrm{m}), \mathrm{K}=\left[\mathrm{t}^{*} \mathrm{~m}\right][4]$. In this study, the mass transfer coefficient was determined on the basis of average molecular weight of multicomponent dairy protein waste [25.6 Kilo Dalton (KDa) as shown in table1] calculated from the respective molar mass fraction of individual proteins (Bovine serum albumin-5\%, $\beta$-lactoglobulin$50 \%, \alpha$-Lactalbumin-12\%, Immnoglobulin-10\%, Bovine lactoferrin$1 \%$, Bovine lactoperoxidase- $0.5 \%$.).

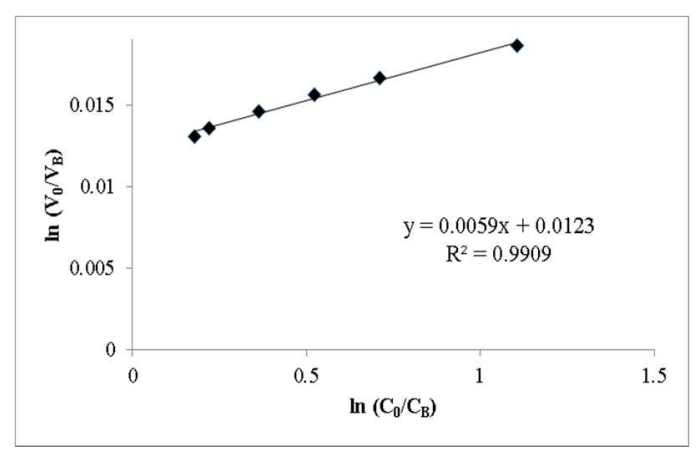

Fig. 6: $\ln (\mathrm{VO} / \mathrm{VB})$ vs. $\ln \left(\mathrm{C}_{0} / \mathrm{C}_{\mathrm{B}}\right)$ Curve for $(\lambda)$ determination

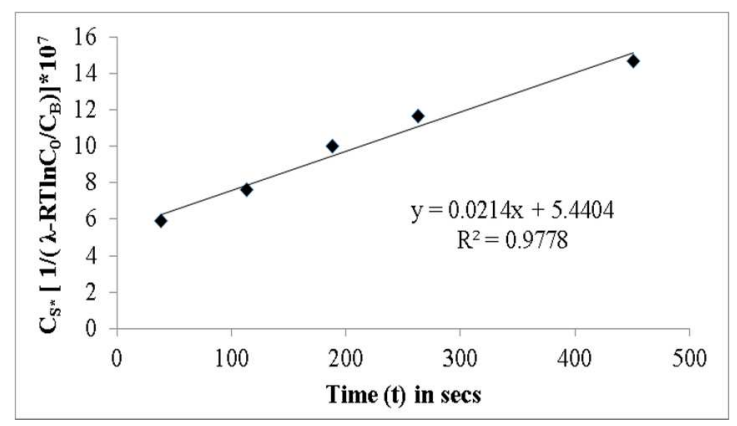

Fig. 7: $C_{s^{*}}\left[1 /\left(\lambda-R T \ln C_{0} / C_{B}\right)\right]^{*} 10^{7}$ vs. time (t) plot for $K$ determination 


\section{RESULTS}

\section{Determination of $\lambda$ and $K$ values}

From fig. 6, $\left[1 /\left(\mathrm{e}^{\lambda \mathrm{RT}}-1\right)\right]=0.0059$ (slope) and $\lambda=3140 \mathrm{cal} / \mathrm{mol}$ approximately.

From fig. 7, K $\left[\mathrm{As}_{\mathrm{s}} / \mathrm{V}_{\mathrm{s}}\right]=(\mathrm{K} / \mathrm{t})=0.021 * 10^{-7}$ (slope). So, $\mathrm{K}=[\mathrm{t}]^{*}$ $\left[0.0218^{*} 10^{-7}\right]=6.041^{*} 0.0218^{*} 10^{7}=12.68^{*} 10^{-9} \mathrm{~mol} / \mathrm{cal} / \mathrm{cm}^{2} / \mathrm{s}, \mathrm{t}=$ foam thickness $=6.014 \mathrm{~cm}$ (calculated from $\mathrm{R}, \lambda, \mathrm{T}(298 \mathrm{~K})$ and $(\mathrm{d} \gamma / \mathrm{dc})=(-$ 0.329 ) from table 1 .
Foam thickness $(t)=\left(V_{s} / A_{s}\right)$ was calculated by the equation: $\left[1 /\left(\mathrm{e}^{\lambda \mathrm{RT}}-1\right)\right]=(1 / \mathrm{t} \mathrm{RT})(-\mathrm{d} \gamma / \mathrm{dc})$.

\section{Effect of $\mathrm{pH}$ at a fixed GFR of $350 \mathrm{ml} / \mathrm{min}$}

Effect of $\mathrm{pH}$ of feed solution at a fixed GFR was recorded in table 5 and represented in fig. 9. The maximum values were recorded with enrichment ratio $\left(E_{R}=49.09\right)$ and percent recovery $\left(\% \mathrm{R}_{\mathrm{p}}=98.18\right)$ for total protein as well as BLP of $0.49 \%(\mathrm{w} / \mathrm{w})$ in enriched protein extract (foamate) at $\mathrm{pH}$ 5.5. All data were found in the order of pH5.5>2.5>8.5 respectively.

Table 4: Experimental results showing the effect of changing GFR at pH5.5

\begin{tabular}{|c|c|c|c|c|c|c|c|c|c|}
\hline $\begin{array}{l}\text { Lot } \\
\text { No. }\end{array}$ & $\begin{array}{l}\text { Exp } \\
\text { No. }\end{array}$ & pH & $\begin{array}{l}\text { Feed conc. } \\
(\mu \mathrm{g} / \mathrm{ml}) \\
\left(\mathrm{C}_{\mathrm{I}}\right)\end{array}$ & $\begin{array}{l}\text { Gas flow } \\
\text { rate } \\
(\mathrm{ml} / \mathrm{min})\end{array}$ & $\begin{array}{l}\text { Concentration in } \\
\text { foamate (CS) } \\
(\mu \mathrm{g} / \mathrm{ml})\end{array}$ & $\begin{array}{l}\text { Enrichment } \\
\text { ratio }\left(E_{R}\right)\end{array}$ & $\begin{array}{l}\% \mathrm{R}_{\mathrm{p}} \\
\text { (Total } \\
\text { protein) }\end{array}$ & $\begin{array}{l}\text { (BLP) } \\
\%(w / w)\end{array}$ & $\begin{array}{l}\text { Heat of } \\
\text { desorption } \\
\lambda(\mathrm{cal} / \mathrm{mol})\end{array}$ \\
\hline 1 & 2 & 5.5 & 400 & 250 & 13478 & 33.70 & 77.50 & 0.38 & 2907 \\
\hline 2 & 2 & 5.5 & 500 & 250 & 20898 & 34.84 & 91.95 & 0.44 & 2833 \\
\hline 3 & 2 & 5.5 & 600 & 250 & 22295 & 37.16 & 81.75 & 0.39 & 2991 \\
\hline 4 & 2 & 5.5 & 400 & 300 & 15087 & 37.72 & 86.75 & 0.41 & 3420 \\
\hline 5 & 2 & 5.5 & 500 & 300 & 20207 & 40.41 & 92.95 & 0.46 & 2878 \\
\hline 6 & 2 & 5.5 & 600 & 300 & 22595 & 37.65 & 82.85 & 0.40 & 3204 \\
\hline 7 & 2 & 5.5 & 400 & 350 & 16718 & 41.80 & 91.85 & 0.45 & 3127 \\
\hline 8 & 2 & 5.5 & 500 & 350 & 24545 & 49.09 & 98.18 & 0.49 & 3360 \\
\hline 9 & 2 & 5.5 & 600 & 350 & 24585 & 40.98 & 83.75 & 0.42 & 3326 \\
\hline
\end{tabular}

Feed volume $=1$ liter; foamate collection time $=55 \mathrm{~min}$

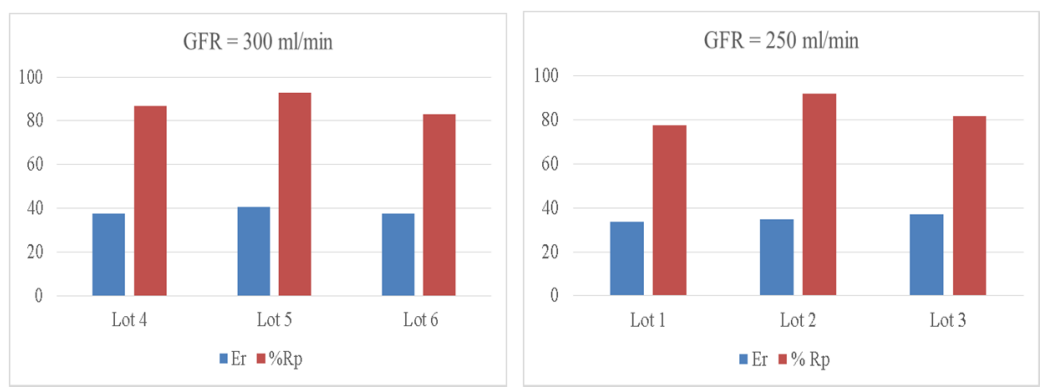

(A)

(B)

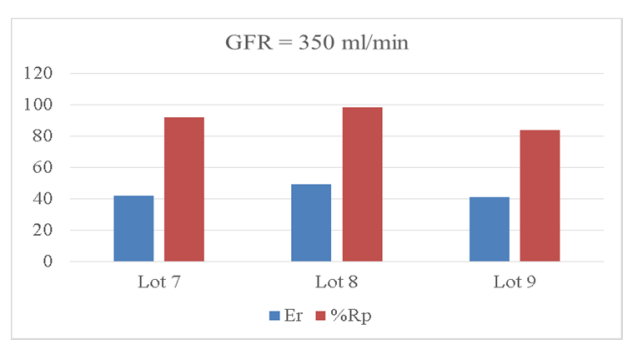

(C)

Fig. 8: Effect of different GFR: (A) [250 ml/min], (B) [300 ml/min], (C) $[350 \mathrm{ml} / \mathrm{min}]$ on $\mathrm{E}_{\mathrm{R}}$ and $\% \mathrm{Rp}$ at $\mathrm{pH} 5.5$ of feed solution

Table 5: Experimental results showing the effect of pH at GFR $350 \mathrm{ml} / \mathrm{min}$

\begin{tabular}{|c|c|c|c|c|c|c|c|c|c|}
\hline $\begin{array}{l}\text { Lot } \\
\text { No. }\end{array}$ & $\begin{array}{l}\text { Exp } \\
\text { No }\end{array}$ & pH & $\begin{array}{l}\text { Feed conc. } \\
(\mu \mathrm{g} / \mathrm{ml})\left(C_{\mathrm{I}}\right)\end{array}$ & $\begin{array}{l}\text { Gas flow } \\
\text { rate } \\
(\mathrm{ml} / \mathrm{min})\end{array}$ & $\begin{array}{l}\text { Concentration in } \\
\text { foamate }\left(\mathrm{C}_{s}\right) \\
(\mu \mathrm{g} / \mathrm{ml})\end{array}$ & $\begin{array}{l}\text { Enrichment } \\
\text { ratio }\left(E_{R}\right)\end{array}$ & $\begin{array}{l}\% \mathrm{Rp} \\
\text { (Total } \\
\text { protein) }\end{array}$ & $\begin{array}{l}\text { (BLP) } \\
\%(w / w)\end{array}$ & $\begin{array}{l}\text { Heat of } \\
\text { desorption } \\
\lambda(\text { cal } / \mathrm{mol})\end{array}$ \\
\hline 8 & 1 & 2.5 & 500 & 350 & 20440 & 40.90 & 79.91 & 0.40 & 3330 \\
\hline 8 & 2 & 5.5 & 500 & 350 & 24545 & 49.09 & 98.18 & 0.49 & 3360 \\
\hline 8 & 3 & 8.5 & 500 & 350 & 19950 & 39.90 & 77.85 & 0.39 & 3140 \\
\hline
\end{tabular}

Effect of changing GFR at a fixed pH 5.5 and $C_{I} 500 \mu \mathrm{g} / \mathrm{ml}$ of feed solution

From table 4 and fig. 8, 10, it was found that enrichment ratio $\left(E_{R}\right)$ and percent recovery $(\% \mathrm{Rp})$ of total protein as well as mass $\%$ of BLP in foamate enhanced with the increase of GFR at fixed pH 5.5 and $\mathrm{C}_{\mathrm{l}} 500$ $\mu \mathrm{g} / \mathrm{ml}$. From experimental results recorded in table 4, it was observed that the enrichment ratio $\left(E_{R}\right)$, percent recovery $(\% \mathrm{Rp})$ and $\mathrm{mg} \%$ of BLP in extract increased as a whole when GFR changed gradually from the values of 250,300 and $350 \mathrm{ml} / \mathrm{min}$ respectively. 


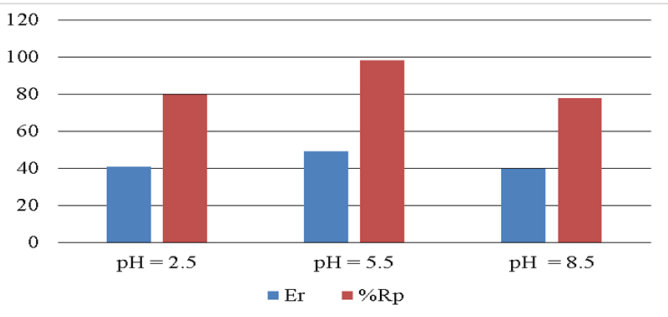

Fig. 9: Effect of varying $\mathrm{pH}(2.5 ; 5.5$ and 8.5$)$ on $E_{R}$ and $\% R_{p}$

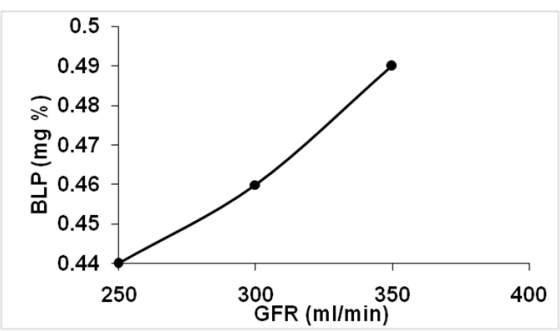

Fig. 10: Effect of GFR on mass \% (w/w) of Lactoperoxidase at $\mathrm{pH}$ 5.5 and feed concentration $500 \mu \mathrm{g} / \mathrm{ml}$

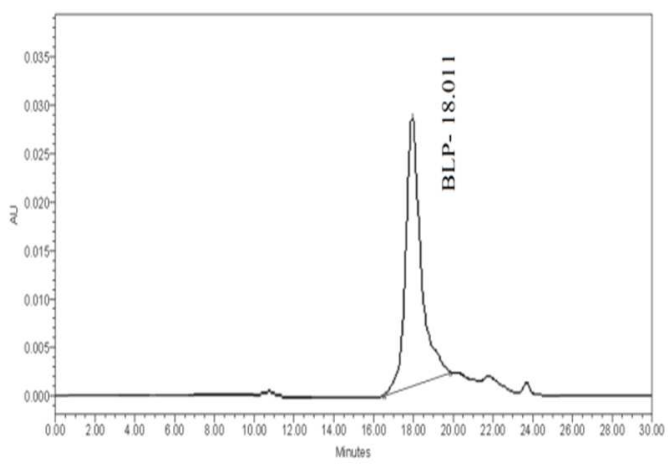

(A)

\section{Effect of superficial gas velocity (SGV) on\% gas hold up ( $\varepsilon^{*}$ )}

The effect of superficial gas velocity (SGV) on \% gas hold and \% Rp were represented in fig. 4. Gas hold up enhances linearly up to the superficial gas velocity (SGV) of $0.199 \mathrm{~cm} / \mathrm{s}$. In the present study, SGV was maintained in the range of $0.0829-0.116 \mathrm{~cm} / \mathrm{s}$ as shown in table 2 . Percent recovery $(\% \mathrm{Rp})$ is enhanced with the increase of the interfacial area.

\section{Effect of ionic concentration (IC) on \% gas hold up at a fixed GFR $250 \mathrm{ml} / \mathrm{min}$}

From table 3 and fig. 5 , it was observed that values of $E_{R}$ and $\% R p$ increased from $0.0125 \mathrm{gmol} / \mathrm{l}$ to $0.1 \mathrm{gmol} / \mathrm{l}$ and after reduced at 0.15 gram-mole/l. The maximum \% gas hold up $\left(\varepsilon^{*}\right)$ was noted 0.905 at $0.1 \mathrm{gmol}$ of $\mathrm{NaCL} / \mathrm{l}$ of feed solution as ionic concentration (Ic) of feed [20].

\section{Quantification of BLP by HPLC method}

The mean $\mathrm{R}_{\mathrm{t}}$ was observed for lactoperoxidase at $18.01 \pm 0.03 \mathrm{~min}$ by comparing between standard fig. 11 (A) and dairy waste protein chromatogram fig. 11 (B). The calibration range of BLP was found to be $100-800 \mu \mathrm{g} / \mathrm{ml}$, with the linear equation $\mathrm{Y}=$ 184006.75X+44218, with the coefficient of determinants $\left(\mathrm{r}^{2}\right)$ of 0.994. The amount of BLP was found $0.49 \%(\mathrm{w} / \mathrm{w})$ of enriched protein extract of foamate.

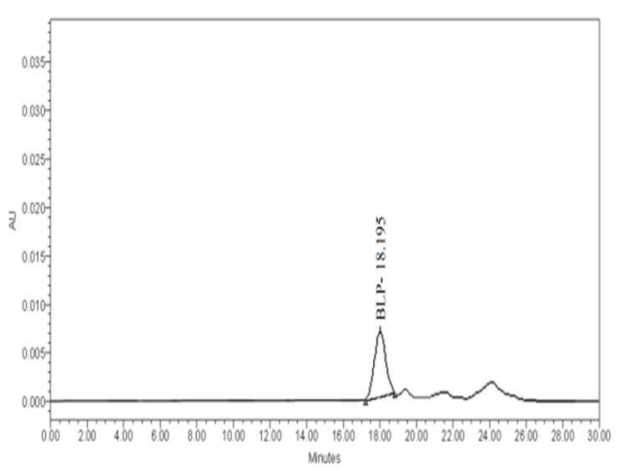

(B)

Fig. 11: RP-HPLC chromatogram of BLP in (A) Standard; (B) in enriched foamate

\section{DISCUSSION}

From table 1 , it was noted $[\mathrm{d} \gamma / \mathrm{dc}]$ value of protein waste solution without SDS $\left(-0.0329\right.$ dynes $\left./ \mathrm{cm}^{2} / \mu \mathrm{g}\right)$ more than that of SDS and protein waste solution mixture, so the addition of SDS have no effect on CMC. "Ekichi et al. (2005) have also remarked that optimum foaming process is attained below $750 \mu \mathrm{g} / \mathrm{ml}$ with a proper gas flow rate which will have a positive outcome on protein enrichment" (fig. 1) [21].

In foam fractionation experiment, $\mathrm{pH}$ of feed solution plays a vital role in controlling the adsorption of protein at the gas-liquid interface (bubble's surface). Isoelectric $\mathrm{pH}$ (pI) of all the major and minor dairy waste proteins are nearly 5.5 and 9.0 respectively as mentioned in table1 $[16,17]$. From table 5 and fig. 10 , it was noted that enrichment factor $\left(E_{R}\right)$ and percent recovery $(\% R p)$ were in the order of $\mathrm{pH} 5.5>\mathrm{pH} 2.5>8.5$. This is because at $\mathrm{pH} 5.5$, all the major proteins prefer hydrophobic adsorption at their isoelectric $\mathrm{pH}$. Minor proteins such as BLF and BLP having pI approximately 9.0>5.5 will behave cationic and form a strong hydrophobic complex with anionic surfactant SDS to adsorb maximum on the surface of the bubble [22, 23]. At $\mathrm{pH} 2.5<\mathrm{pI}$, major proteins(more than $95 \%$ of total protein) get cationic and fastened by columbic attraction with anionic SDS to form surfactant links between lamella (intra space of foam) by enhancing the foam's tackiness and rigidity which will resist the rising flow of liquid causing reduction of enrichment and recovery. At $\mathrm{pH} 8.5(>\mathrm{pI}$ of major proteins), major proteins become anionic and columbic repulsion between proteins and SDS-protein complex molecules will repel each other reducing thickness and viscosity of film than that at
$\mathrm{pH}$ 2.5. So, foam at $\mathrm{pH} 8.5$ is quite wet and less dense than at $\mathrm{pH} 8.5$. Minor proteins being heavy find difficulty for adsorption at pH8.5 (adjacent to their $\mathrm{pI}=9.0$ ) due to weak hydrophobicity of raw protein than protein-SDS complex at $\mathrm{pH} 5.5$ and 2.5 [22].

From (fig. 4, 9 and 10) and (table 2 and 4), increase of $E_{R}, \% R_{p}$ of total proteins and $\%(\mathrm{w} / \mathrm{w})$ of BLP in foamate were found to increase due to the steady enhancement of SGV and GFR. This can be elucidated by the fact that the gradual increase of both the values generate an additional number of bubbles followed by an increase of the interfacial area of adsorption. From fig. 5 and table3, it was observed that the effect of inorganic ions ( $\mathrm{NaCL}$ ) enhanced the gas hold up volume, $E_{R}$ and $\% R_{p}$ at the maximum of $0.1(M)$ of ionic concentration which is below critical concentration of NaCL $[0.145$ (M)] due to inhibition of coalescence between the bubbles and increase of interfacial area of adsorption by formation of microbubbles [20]. The SDS-protein complex enhances the foam properties like width, flexibility, and sturdiness of foam membranes and foamability of proteins for the enrichment of adsorption.

In fig. 12, linearity indicates the theory of material balance of proteins of total mass $\left(\mathrm{M}_{\mathrm{T}}\right)$ in feed equal to the sum of masses in foamate and residue $\left(\mathrm{M}_{\mathrm{T}}=\mathrm{M}_{\mathrm{S}}+\mathrm{M}_{\mathrm{R}}\right)$ indicating minimum loss of material. Rate of separation and time for $50 \%$ separation $\left(\mathrm{t}_{50 \%}\right)$ can be determined from the slope and point of intersection of curves. Based on the experimental condition of exp no 2 of lot no $9, \lambda$ and $K$ values were determined from fig. 6,7 and equations 5,6 at the values of $3140 \mathrm{cal} / \mathrm{mol}$ and $12.686 * 10^{-9} \mathrm{gm} \mathrm{mol} \mathrm{cal}^{-1} \mathrm{~cm}^{-2} \mathrm{~s}$ respectively. 




Fig. 1: Plot of surface tension vs concentration of dairy protein waste solution



Fig. 2: Experimental set up for foam fractionation

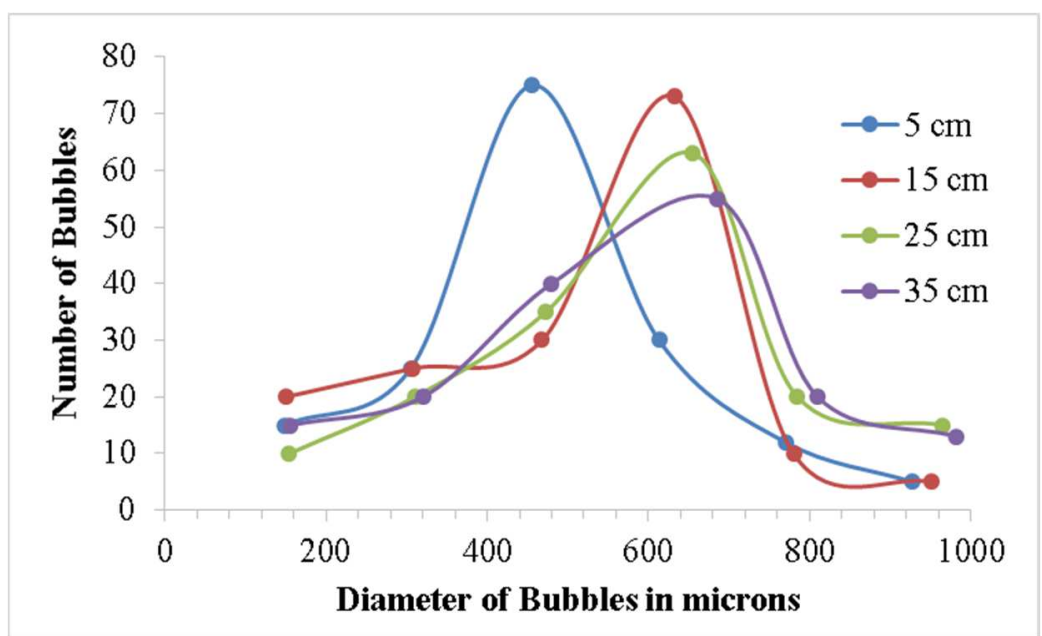

Fig. 3: Bubble distribution at $S G V 0.083 \mathrm{~cm} / \mathrm{s}$ 


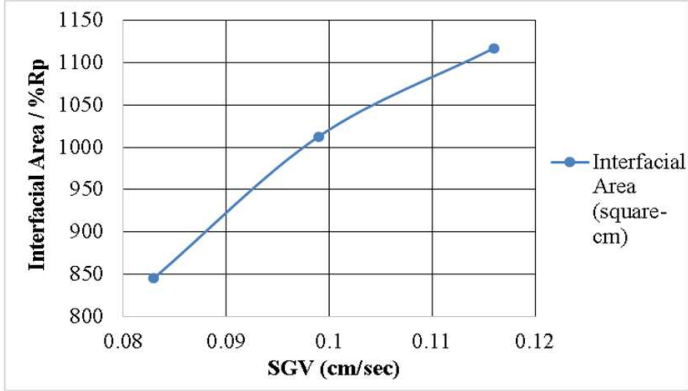

Fig. 4: Effect of superficial gas velocity on the interfacial area



Fig. 5: Effect of ionic concentration on $E_{R}$ and $\% R_{p}$



Fig. 6: In (V0/VB) vs. $\ln \left(C_{0} / C_{B}\right)$ Curve for $(\lambda)$ determination

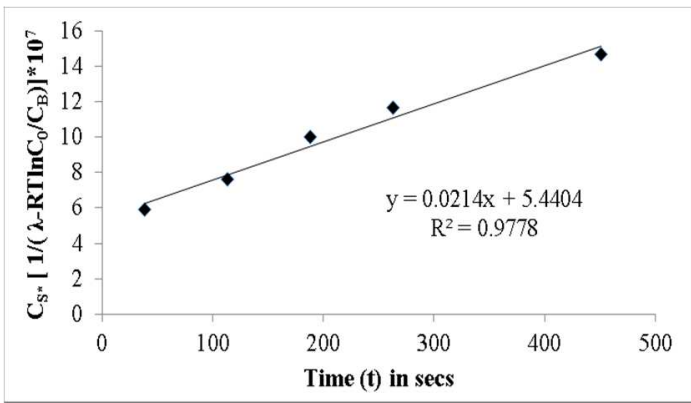

Fig. 7: $C_{S^{*}}\left[1 /\left(\lambda-R T \ln C_{0} / C_{B}\right)\right]^{*} 10^{7}$ vs. time $(t)$ plot for $K$ determination

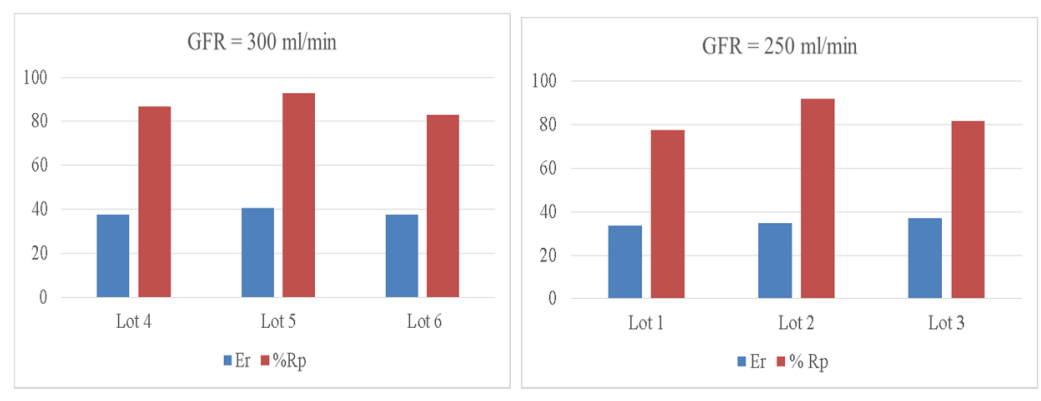

(A)

(B)

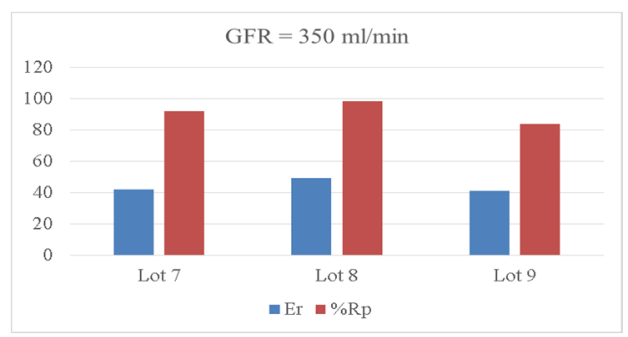

(C)

Fig. 8: Effect of (A) [GFR $250 \mathrm{ml} / \mathrm{min}$ ], (B) [GFR300 $\mathrm{ml} / \mathrm{min}$ ], (C) [GFR300 $\mathrm{ml} / \mathrm{min}$ ] on $E_{R}$ and\% $R_{p}$

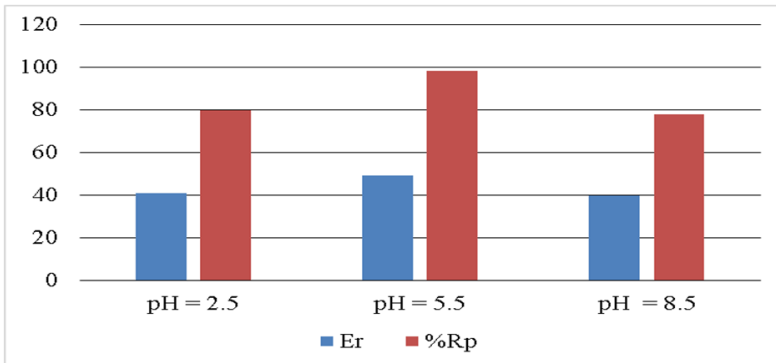

Fig. 9: Effect of varying $\mathrm{pH}\left(2.5 ; 5.5\right.$ and 8.5) on $\mathrm{E}_{\mathrm{R}}$ and $\% \mathrm{R}_{\mathrm{p}}$



Fig. 10: Effect of GFR on mass $\%(w / w)$ of Lactoperoxidase at $p H$ 5.5 and feed concentration $500 \mu \mathrm{g} / \mathrm{ml}$ 


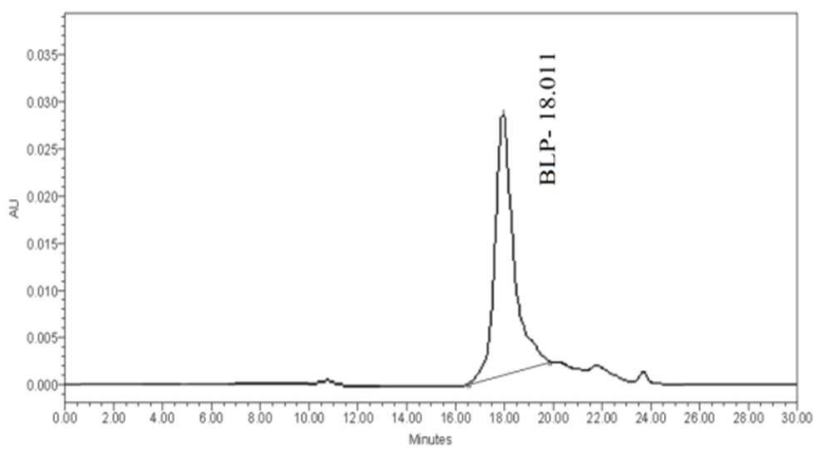

(A)

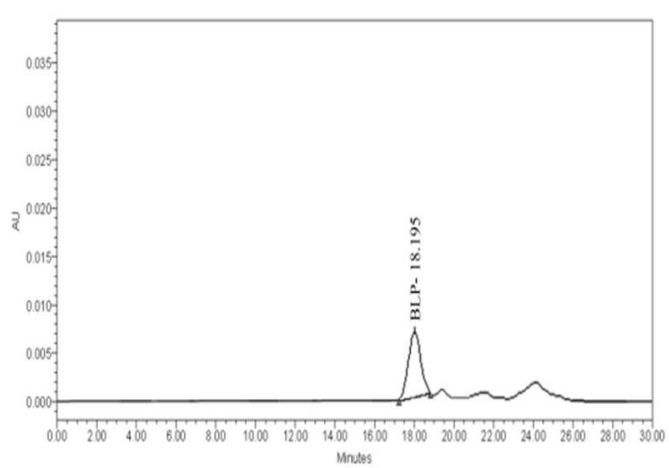

(B)

Fig. 11: RP-HPLC chromatogram of BLP in (A) Standard; (B) Enriched foamate



Fig. 12: Material balance diagram of experiment no 2 of lot 8

Table 1: Characteristics of medicinal proteins in dairy waste

\begin{tabular}{|c|c|c|c|c|c|}
\hline Medicinal protein in dairy waste & $\begin{array}{l}\text { Mol. wt. } \\
\left(\mathrm{Da}^{*} \mathbf{1 0}^{3}\right)\end{array}$ & Isoelectric pH(pI) & $\begin{array}{l}{[\mathrm{d} \gamma / \mathrm{dc}]} \\
(\mathrm{dyne} \mathrm{cm} 2 / \mu \mathrm{g})\end{array}$ & $\begin{array}{l}\text { Range of conc. }(\mu \mathrm{g} / \mathrm{ml}) \\
\text { of constant slope }\end{array}$ & $\begin{array}{l}\text { CMC } \\
(\mu \mathrm{g} / \mathrm{ml})\end{array}$ \\
\hline BSA(major) & 69 & 5.1 & ---- & ----- & $-\cdots$ \\
\hline $\mathrm{BLF}$ (minor) & 84 & 9.0 & 0.082 & $5-150$ & 150 \\
\hline $\mathrm{BLP}($ minor $)$ & 89 & 9.6 & ----- & ----- & ----- \\
\hline$\alpha$-LA(major) & 14 & 5.3 & ------ & ----- & ----- \\
\hline$\beta$-LG(major) & 18.30 & 4.8 & ----- & ------ & ----- \\
\hline IG(major) & 100 & 5.5 & ----- & ------ & ----- \\
\hline Dil. protein waste & 25.60 & 5.2 & 0.329 & $50-750$ & 750 \\
\hline Dil.(Protein waste+SDS) [1.5:1(w/w)] & ------- & ------ & 0.301 & $85-800$ & 800 \\
\hline
\end{tabular}

Table 2: Effect of superficial gas velocity on the interfacial area

\begin{tabular}{|c|c|c|c|c|c|c|c|}
\hline SGV (cm/s) & $\begin{array}{l}\text { Gas flow rate } \\
(\mathrm{ml} / \mathrm{min})\end{array}$ & $\begin{array}{l}\text { Sauter mean } \\
\text { diameter } \\
d_{32}(\mathrm{~cm})\end{array}$ & $\begin{array}{l}\text { \% gas hold up } \\
\left(\varepsilon^{*} 100\right)\end{array}$ & Interfacial area $\left(\mathrm{cm}^{2}\right)$ & $\begin{array}{l}\text { Percent recovery } \\
\text { (\%Rp) }\end{array}$ & $\begin{array}{l}\text { Feed density } \\
\text { (g/cc) }\end{array}$ & $\begin{array}{l}\text { Feed } \\
\text { viscosity } \\
\text { (Poise) }\end{array}$ \\
\hline 0.083 & 250 & 0.0621 & 0.90 & 845.09 & 90.98 & 1.235 & 0.0095 \\
\hline 0.099 & 300 & 0.0705 & 1.19 & 1012.85 & 93.99 & & \\
\hline 0.116 & 350 & 0.0821 & 1.38 & 1117.29 & 98.18 & & \\
\hline
\end{tabular}

Table 3: Effect of ionic concentration on $\left(E_{R}\right)$ and (\%Rp)

\begin{tabular}{llll}
\hline Molar Ionic concentration & Percent gas hold up $\left(\boldsymbol{\varepsilon}^{*} \mathbf{1 0 0}\right)$ & Enrichment ratio $\left(\mathrm{E}_{\mathrm{R}}\right)$ & Percent recovery $(\mathbf{\%} \mathbf{R})$ \\
\hline 0.0125 & 0.70 & 32.80 & 70.40 \\
0.05 & 0.785 & 33.39 & 78.80 \\
0.1 & 0.905 & 40.45 & 90.99 \\
0.15 & 0.810 & 36.52 & 80.35 \\
\hline
\end{tabular}


Table 4: Experimental results showing the effect of changing GFR at pH5.5

\begin{tabular}{|c|c|c|c|c|c|c|c|c|c|}
\hline $\begin{array}{l}\text { Lot } \\
\text { No. }\end{array}$ & $\begin{array}{l}\text { Exp } \\
\text { No. }\end{array}$ & pH & $\begin{array}{l}\text { Feed conc. } \\
(\mu \mathrm{g} / \mathrm{ml})\left(C_{I}\right)\end{array}$ & $\begin{array}{l}\text { Gas flow } \\
\text { Rate } \\
(\mathrm{ml} / \mathrm{min})\end{array}$ & $\begin{array}{l}\text { Concentration in } \\
\text { foamate } \\
(\mathrm{CS})(\mu \mathrm{g} / \mathrm{ml})\end{array}$ & $\begin{array}{l}\text { Enrichment } \\
\text { ratio }\left(E_{R}\right)\end{array}$ & $\begin{array}{l}\% R_{p} \\
\text { (Total } \\
\text { protein) }\end{array}$ & $\begin{array}{l}\text { (BLP) } \\
\%(w / w)\end{array}$ & $\begin{array}{l}\text { Heat of } \\
\text { desorption } \\
\lambda(\mathrm{cal} / \mathrm{mol})\end{array}$ \\
\hline 1 & 2 & 5.5 & 400 & 250 & 13478 & 33.70 & 77.50 & 0.38 & 2907 \\
\hline 2 & 2 & 5.5 & 500 & 250 & 20898 & 34.84 & 91.95 & 0.44 & 2833 \\
\hline 3 & 2 & 5.5 & 600 & 250 & 22295 & 37.16 & 81.75 & 0.39 & 2991 \\
\hline 4 & 2 & 5.5 & 400 & 300 & 15087 & 37.72 & 86.75 & 0.41 & 3420 \\
\hline 5 & 2 & 5.5 & 500 & 300 & 20207 & 40.41 & 92.95 & 0.46 & 2878 \\
\hline 6 & 2 & 5.5 & 600 & 300 & 22595 & 37.65 & 82.85 & 0.40 & 3204 \\
\hline 7 & 2 & 5.5 & 400 & 350 & 16718 & 41.80 & 91.85 & 0.45 & 3127 \\
\hline 8 & 2 & 5.5 & 500 & 350 & 24545 & 49.09 & 98.18 & 0.49 & 3360 \\
\hline 9 & 2 & 5.5 & 600 & 350 & 24585 & 40.98 & 83.75 & 0.42 & 3326 \\
\hline
\end{tabular}

Feed Volume $=1$ liter; foamate collection time $=55 \mathrm{~min}$

Table 5: Experimental results showing the effect of $\mathrm{pH}$ at GFR $350 \mathrm{ml} / \mathrm{min}$

\begin{tabular}{|c|c|c|c|c|c|c|c|c|c|}
\hline $\begin{array}{l}\text { Lot } \\
\text { No. }\end{array}$ & $\begin{array}{l}\text { Exp } \\
\text { No }\end{array}$ & pH & $\begin{array}{l}\text { Feed conc. } \\
(\mathrm{mcg} / \mathrm{ml}) \\
\left(\mathrm{C}_{\mathrm{I}}\right)\end{array}$ & $\begin{array}{l}\text { Gas flow } \\
\text { rate } \\
(\mathrm{ml} / \mathrm{min})\end{array}$ & $\begin{array}{l}\text { Concentration in } \\
\text { foamate }(\mathrm{CS}) \\
(\mathrm{mcg} / \mathrm{ml})\end{array}$ & $\begin{array}{l}\text { Enrichment } \\
\text { ratio }\left(E_{R}\right)\end{array}$ & $\begin{array}{l}\% \text { Rp } \\
\text { (Total } \\
\text { protein) }\end{array}$ & $\begin{array}{l}\text { (BLP) } \\
\%(w / w)\end{array}$ & $\begin{array}{l}\text { Heat of } \\
\text { desorption } \\
\lambda(\mathrm{cal} / \mathrm{mol})\end{array}$ \\
\hline 8 & 1 & 2.5 & 500 & 350 & 20440 & 40.90 & 79.91 & 0.40 & 3330 \\
\hline 8 & 2 & 5.5 & 500 & 350 & 24545 & 49.09 & 98.18 & 0.49 & 3360 \\
\hline 8 & 3 & 8.5 & 500 & 350 & 19950 & 39.90 & 77.85 & 0.39 & 3140 \\
\hline
\end{tabular}

\section{CONCLUSION}

It is noted that the foam fractionation is a useful unit operation to enhance the concentration of medicinal proteins from dilute dairy waste as well as to eliminate pollutant proteins to certain level from dairy wastewater to control environmental pollution. The method was found to have optimal effectiveness at initial concentration of $500 \mathrm{mcg} / \mathrm{ml}$, gas flow rate $350 \mathrm{ml} / \mathrm{min}$, waste surfactant mass ratio 1.5:1 and ionic concentration $0.1 \mathrm{gm}$-mole of NaCL per liter of feed at pH5.5. Superficial gas velocity and ionic concentration enhance the interfacial area for adsorption by increasing the size and number of bubbles. Mass transfer coefficient inspected in this study was to some extent high than that of earlier studies. The difference in value may be due to the impact of SDS and inorganic electrolyte (NaCL) resulting in adsorption of high molecular weight proteins such as lactoferrin and lactoperoxidase. Evaluation of the performance of experiment number 2 of lot 8 was found acceptable. The study focused foam fractionation as the lucrative unit operation to concentrate thermo labile medicinal proteins as well as eliminate pollutant proteins from dairy wastewater for coming days

\section{ACKNOWLEDGMENT}

Authors would like to acknowledge all the researcher workers who are engaged to develop this novel and promising unit operation through their untiring effort for technological development so that it can be applied in the practical field.

\section{AUTHORS CONTRIBUTIONS}

All authors contributed uniformly to this research work and preparation of this manuscript.

\section{CONFLICT OF INTERESTS}

Authors state no conflict of interest

\section{REFERENCES}

1. Durham RJ, Hourigan JA. Waste management and co-product recovery in dairy processing. In: Waldron K. editor. Handbook of waste management and co-product recovery in food processing. $1^{\text {st }}$ ed. England: Woodland Publishers Ltd; 2007. p. 332-87.

2. Bulletin IDF (International Diary Federation); 2017. p. 489.

3. UN-OECD (Organization for Economic Cooperation and Development): Special Report; 2017.

4. Lemlich R. Adsorptive bubble separation techniques. $1^{\text {st }}$ ed. Academic Press: New York: Elsevier; 1972. p. 159-73.

5. Yuki YO, Chou J. Foam fractionation process. McGraw Hill Publishers: London; 1979.
6. Datta PK, Ghosh A, Chakraborty P, Gangopadhyay A. Foam fractionation in the separation of pharmaceutical biomolecules: a promising unit operation for industrial process and waste control. J Fundamental Pharm Res 2015;3:33-41.

7. Backeh M, Leupoid G, Ekichi P, Parlar H. Rapid quantitative extraction of carnosic acid from rosemary (Rosemarinous officinalis) by isoelectric focused adsorptive bubble chromatography. J Agric Food Chem 2003b;51:1297-301.

8. Holmstorm B. Foam fractionation of streptokinase from crude culture filtrates. J Biotechnol Bioeng 1968;10:551-2.

9. Rubio J, Tessele F. Removal of heavy metal ions by an adsorptive particulate floatation. J Min Eng 1997;10:671-9.

10. Kim YS, Choi YS, Lee YL. Determination of zinc and lead by solvent sublation using ion-pair. Bull Korean Chemical Society 2001;22:821-6.

11. Qu YH. Recovery of surfactant SDS and $\mathrm{Cd}^{2+}$ from permeate in MEUF using a continuous foam fractionator. J Hazard Mater 2008;155:32-8.

12. Durham RJ, Hourigan JA, Sleigh RW, Johnson RL. Whey fractionation: wheying up the consequences. Food Australia 1997;49:460-5.

13. Jam MS, Van Hooijdonk ACM. Occurrence, structure, biochemical properties and technological characteristics of lactoferrin. Br J Nutr 2000;84 Suppl 1:11-7.

14. Giansanti F, Panella G, Labolfe L, Antonini G. Lactoferrin from milk: nutraceutical and pharmacological properties. J Pharm 2016;9:1-15.

15. Kussendrager KD, Van Hooijdonk ACM. Lactoperoxidase: physicochemical properties, occurrence, mechanism of action and applications. Br J Nutr 2000;84 Suppl 1:19-25.

16. Michel MJ, Pouliot Y, Britten M, Noel I, Lebrun R. Study on the molecular mass changes of bovine k-casein glycomacropeptide and on its separation in ultra-filtration with and without application of electric fields. J Diary Sci 2002;85:Suppl 1.

17. Marshall KR. Industrial isolation of milk proteins: Whey proteins. In: Fox PF. editor. Development in diary chemistry, proteins. ed. London: Chap. 11. Appl Sci Publishers; 1982.

18. Noel J, Prokop A, Tanner RD. Foam fractionation of a dilute solution of bovine lactoferrin. J Appl Biochem Biotechnol 2002;98-100:395-402.

19. Saleh ZS, Hossain HdM. A study of the separation of proteins from multi-component mixtures by a semi-batch foaming process. Chemical Engineering and Processing; Elsevier Publishers Ltd; 2001;40:371-8.

20. Besagni G, Inzoli F. Influence of electrolyte concentration on hold up flow regime transition and local flow properties in a 
large scale bubble column. $33^{\text {rd }}$ Italian Union of Thermo fluiddynamics Heat Transfer Conference. J Physics: Conference Series 2015:655. DOI:10.1088/1742-6596/655/1/012039.

21. Ekichi P, Backleh SM, Palar H. High-efficiency enrichment of total and single whey proteins by $\mathrm{pH}$ controlled foam fractionation. Int J Food Sci Nutr 2005;56:223-9.
22. Suzuki A, Yasuhara HS, Maruyama H. Selective foam separation of binary proteins solution by SDS complexation method. J Colloidal Interface Sci 2002;253:402-8.

23. Fuda E, Jauregi P, Pyle DL. Recovery of lactoferrin and lactoperoxidase from sweet whey using colloidal gas aphrons (CGAs) generated from an anionic surfactant AOT. J Biotechnol Progress 2004;20:514-25. 